\title{
Specifičnosti studije izvodljivosti projekta ANUBIH Opća enciklopedija Bosne i Hercegovine
}

\author{
Miloš Trifković \\ Akademija nauka i umjetnosti Bosne i Hercegovine, Sarajevo \\ mtrifkovic@anubih.ba
}

SAŽETAK: Objavljivanje prvih dvaju tomova, u nacionalnom ili teritorijalnom smislu, partikularnih enciklopedija, Hrvatske enciklopedije Bosne i Hercegovine i Enciklopedije Republike Srpske, u intelektualnoj je javnosti otvorila pitanje stvaranja Opće enciklopedije Bosne i Hercegovine. Ta bi enciklopedija morala posmatrati $\mathrm{BiH}$ kao cjelovitu, jedinstvenu i zasebnu historijsku, socijalnu i državnu tvorevinu isključivo na osnovu naučno utvrđenih činjenica. Predsjedništvo je odlučilo da se ANUBiH angažuje na ovom projektu. Nakon faze pripremnih radnji Akademija je zaključila da se u postojećim društvenim uslovima najprije mora sačiniti iscrpna studija izvodljivosti za cijeli izdavački poduhvat državne opće enciklopedije. Ovaj rad je prvi odgovor na taj zahtjev. U njemu se na bazi postojećih saznanja o studijama izvodljivosti i enciklopedistici, te sadašnjih i predvidljivih društveno-političkih prilika, utvrđuju najvažniji elementi buduće studije izvodljivosti projekta ANUBiH Opća enciklopedija Bosne i Hercegovine.

Ključni pojmovi: Bosna i Hercegovina; opća enciklopedija; ANUBiH; studija izvodljivosti

\section{Uvod}

Noviji razvoj enciklopedistike u Bosni i Hercegovini ( $\mathrm{BiH})$ počinje nakon Drugog svjetskog rata u sklopu napora cijele društvene zajednice u ovoj oblasti. Njihov nosilac bio je Leksikografski zavod FNRJ u Zagrebu. ${ }^{1}$ Rezultati ove institucije značajno su uticali na enciklopedijske napore i nakon disolucije zajedničke države. ${ }^{2} \mathrm{Za} \mathrm{BiH}$ su

1 Zavod je osnovan 1950. godine. O rezultatima ovog perioda vidjeti: Leksikografski zavod Miroslav Krleža, u: S. Ravlić (ur.) »Hrvatska enciklopedija - mrežno izdanje« (Enciklopedija.hr), 2020., str. 2/3 naročito. Preuzeto s: https://www.enciklopedija.hr/natuknica.aspx?id=35937 (pristupljeno 2. IV. 2020).

2 O Republici Hrvatskoj vidjeti »Enciklopedija« u S. Ravlić (ur.), isto. O Republici Srbiji vidjeti »Srpska enciklopedija - II tom«, Zavod za udžbenike Republike Srbije, Beograd 2014. Preuzeto s: http:// www.knjizara.zavod.co.rs/srpska-enciklopedija-ii-tom. 
posebno važne Opća enciklopedija fugoslavenskog leksikografskog zavoda ${ }^{3}$ i Separat Socijalistička Republika Bosna i Hercegovina iz 1983. godine, koji je rađen uz II. izdanje Enciklopedije Fugoslavije. ${ }^{4}$

Poslije završetka posljednjeg rata u Bosni i Hercegovini započeto je nekoliko leksikografskih poduhvata. Akademija nauka i umjetnosti Bosne i Hercegovine (ANUBiH, Akademija) osnovala je svoj Centar za leksikologiju i leksikografiju (CLL, Centar) 1997. godine, kao nasljednika materijala i zadataka fugoslavike. ${ }^{5}$ Hrvatska zajednica Herceg-Bosna je 2004. godine u Mostaru osnovala Hrvatski leksikografski institut. ${ }^{6}$ Njegovim djelovanjem $»$ na poticaj nekoliko značajnih nacionalnih i vjerskih institucija « ${ }^{7}$ objavljena su dva od četiri toma Hrvatske enciklopedije Bosne $i$ Hercegovine (HEBiH), prvi 2009. ${ }^{8}$ i drugi 2015. godine. »Rad na Enciklopediji Republike Srpske (ERS) formalno-pravno počinje 2007. godine donošenjem entitetskog zakona o ovoj publikaciji.« ${ }^{9}$ Nosilac izrade je Akademija nauka i umjetnosti Republike Srpske (ANURS). Prvi od šest planiranih tomova objavljen je 2017. godine, a drugi godinu dana kasnije.

Pojavom nacionalnih i u teritorijalno partikularnih enciklopedija unutar Bosne i Hercegovine, otvorila se rasprava o njihovoj funkciji i svrsishodnosti rada na opštoj enciklopediji Bosne i Hercegovine.$^{10} \mathrm{U}$ intelektualnoj javnosti se postavilo pitanje zašto se ne radi na savremenoj enciklopedija koja će $\mathrm{BiH}$ posmatrati kao cjelovitu, jedinstvenu i zasebnu historijsku, socijalnu i državnu tvorevinu isključivo na osnovu naučno utvrđenih činjenica. Konkretnu inicijativu i ponudu za sufinansiranje takvog poduhvata Akademiji je 2017. godine uputila Fondacija »Pravda za Bosnu

3 Od 1955. do 1982. godine izašla su tri izdanja ove enciklopedije.

4 Izdavač: JLZ, Zagreb 1983. Glavni urednici su bili prof. dr. Muhamed Filipović i akademik Alojz Benac.

5 Akademik Božidar Matić u intervjuu za prilog radija Slobodna Evropa: Erduan Katana: »Može li BiH imati jedinstvenu enciklopediju«, Radio Slobodna Evropa, 22. 6. 2010. godine. Preuzeto s: https://www.slobodnaevropa.org/a/bih_hrvatska_enciklopedija/2079423.html (pristupljeno 2. IV. 2020).

6 HLI BiH - Hrvatski leksikografski institut Bosne i Hercegovine, Hrvatska zajednica Herceg-Bosna. Preuzeto s: http:/www.hercegbosna.ba/index.php/hz-hb/ustanove/hli-bih-hrvatski-leksikografski-institut-bih (2. 4. 2020); Zoran Krešić, Ivan Anđelić: »Hrvatski leksikografski institut BiH je pred gašenjem«, Večernji list, 14. 11. 2016. Preuzeto s: https://www.vecernji.ba/vijesti/hrvatski-leksikografskiinstitut-bih-je-pred-gasenjem-1128196, pristupljeno 2. IV. 2020.

7 Iva Klobučar Srbić, »Hrvatska enciklopedija Bosne i Hercegovine, sv. 2 (E-J)«, Studia lexicographica, 9 (2015), 1(16), str. 190.

8 Vidjeti Ivan Šabić: Razgovor s dr. Ivanom Markešićem, izvršnim urednikom Hrvatske enciklopedije Bosne i Hercegovine: »Biti Hrvat u BiH ne znači biti protiv BiH«, Vjesnik, 14., 15. i 16. VIII. 2009. str. 60-61.

\footnotetext{
9 Službeni glasnik RS, br. 38/07.

10 Katana, isto,
} 
i Hercegovinu «(Fondacija), Sarajevo, koja okuplja nacionalna udruženja intelektualaca, i »Krug 99«.

Nakon niza razgovora sa Fondacijom, ispitivanja uslova nužnih za izradu enciklopedije u ANUBiH i usvajanja pripremnih dokumenata, Predsjedništvo Akademije je donijelo odluku da se ANUBiH angažira na Općoj enciklopediji Bosne i Hercegovine (dalje: OEBiH ili Enciklopedija). S obzirom na veličinu i značaj ovog angažmana, zaključeno je da se prije traženja finansijskih sredstava za Opću enciklopediju Bosne i Hercegovine uradi studija izvodljivosti za cijeli izdavački poduhvat. ${ }^{11}$

Ovaj rad je sažetak recenzirane i prezentirane interdisciplinarne studije ANUBiH, kojom su dati prvi odgovori na postavljeni zadatak. U njihovom izlaganju akcent će biti na konkretizaciji teorijskih stavova o studiji izvodljivosti na projekt Akademije Opća enciklopedija Bosne i Hercegovine (dalje: Projekt OEBiH).

\section{Principi buduće Opće enciklopedije Bosne i Hercegovine i nužnost izrade studije izvodljivosti Projekta OEBiH}

U periodu odlučivanja o tome da li će se ANUBiH angažovati na izradi Opće enciklopedije Bosne i Hercegovine, pored organizacionih, razmotren je i niz suštinskih pitanja koncepcije i načina izrade Enciklopedije. U raspravi su definisani najvažniji principi koji se tiču sadržaja i politike projekta OEBiH ${ }^{12}$ Oni izražavaju fundamentalni pristup Akademije ovome projektu i granice koje u njegovoj izradi neće biti prekoračene. Zbog toga su utvrđena načela mjerodavna i za studiju izvodljivosti OEBiH (dalje: Studija izvodljivosti).

Sažeto izložena, najvažnija materijalna načela buduće OEBiH su sljedeća:

a) Enciklopedija se zasniva na misiji $\mathrm{ANUBiH},{ }^{13}$ a koncipira i realizuje u okviru Akademije.

b) Predmet Enciklopedije je prvenstveno Bosna i Hercegovina kao cjelovita, jedinstvena i zasebna historijska, socijalna i državna tvorevina. Od opštih znanja u približno polovici teksta će biti obrađena ona koja su od neposrednog interesa za Bosnu i Hercegovinu i njene državljane.

11 Vidjeti Izvod iz zapisnika sa sjednice Predsjedništva ANUBiH od 26. XI. 2019. godine.

12 Vidjeti materijal Radne grupe predsjedništva od 14. I. 2020. godine: »Osnovni principri djelovanja ANUBiH, njenih organa i tijela u izradi studije izvodljivosti Opće enciklopedije Bosne i Hercegovine«, broj: $04-09-2-6-3 / 20$ od 27. I. 2020. godine.

13 Tekst Misije ANUBiH usvojen je na godišnjoj skupštini Akademije od 29. VI. 2017. (https:// www.anubih.ba/index.php/bs/o-akademiji) 
c) Sve natuknice će se zasnivati isključivo na naučno provjerenim podacima i biće prezentirane objektivno.

d) Deset tomova Enciklopedije će biti objavljeno na jezicima koji su u službenoj upotrebi u Bosni i Hercegovini, latiničnim i ćiriličnim pismom, te u skraćenoj verziji i na engleskom jeziku.

e) $\mathrm{OEBiH}$ je dugoročan projekt i dinamična tvorevina. Zahvaljujući elektronskom formatu mijenjat će se i dopunjavati u toku izrade i nakon nje.

f) Posebna pažnja će se posvetiti upravljanju brojnim vanjskim i unutrašnjim rizicima.

Bitni principi politike projekta su :

a) na nivou Države $\mathrm{BiH}$ treba postići konsenzus o svim ključnim pitanjima za izradu Enciklopedije: koncepcija, dugoročno finansiranje, samostalnost ANUBiH itd.

b) Način finansiranja i organizacija rada moraju osigurati izlaženje svih 10 tomova Enciklopedije i dalje iskorištavanje rezultata rada uloženog u njeno stvaranje.

c) Predsjedništvo ANUBiH će u svojstvu glavne redakcije izradu Enciklopedije voditi potpuno samostalno.

d) ANUBiH, njeni organi i tijela, glavna i druge redakcije u pogledu koncepcije, sadržaja i teksta Enciklopedije ne smiju podlijegati bilo kakvim pritiscima i uslovljavanjima, posebno ne od strane finansijera.

e) U pribavljanju i utrošku sredstava za izradu, štampanje i distribuciju Enciklopedije mora postojati potpuna transparentnost i odgovornost svih uključenih subjekata.

f) Načinom izrade i objavljivanja Enciklopedije će se omogućiti da njene natuknice i struktura budu otvoreni za naknadne izmjene i dopune.

Do sada u Bosni i Hercegovini nije završena ni jedna enciklopedija koja bi odgovarala konceptu i načelima Enciklopedije, pa se minimalni uslovi za ostvarenje izloženih principa i uspjeh projekta ANUBiH moraju anticipirati. To su:

a) izgradnja struktura vlasti i promjena stvarnog načina funkcionisanja političkog sistema u pravcu koji će biti povoljan za zajednički intelektualni projekt od opšteg interesa, kakav je OEBiH.

b) Postojanje što šireg društvenog i političkog konsenzusa u pogledu potrebe izrade i ažuriranja $\mathrm{OEBiH}$. 
c) Formiranje posebne projektne organizacije ANUBiH bez svojstva pravnog lica ili kao pravnog lica.

d) Dovoljno i stabilno finansiranje $u$ trajanju od barem dvije decenije, koje u našim uslovima mora imati dominantno budžetski karakter.

e) Okupljanje kritične mase intelektualaca u projektnoj organizaciji i oko nje.

f) Izgradnju specifične infrastrukture kao što su obrazovanje specijalizovanih kadrova, stvaranje bibliotečke i informacione baze.

g) Stvaranje jake mreže subjekata vezanih za projekt - prijatelja OEBiH (stakehodlers). ${ }^{14}$

h) Pojačana međunarodna saradnja u oblasti enciklopedistike.

Ključne pretpostavke za uspješan završetak projekta OEBiH u kontekstu sadašnjih rješenja ustavnog poretka, stanja državne organizacije i realnog funkcionisanja političkog sistema nisu ispunjene. Te činjenice zahtijevaju da se prije pristupanja izradi Enciklopedije sačini studija izvodljivosti ovoga projekta.

\section{Pojam studije izvodljivosti i studije izvodljivosti Projekta OEBiH}

Sintagma »studija izvodljivosti« ili kao opšte prihvaćen engleski tehnički termin »feasibility study«, označava izuzetno široku kategoriju. Studija izvodljivosti se u modernom značenju afirmirala u pripremi velikih infrastrukturnih projekata. ${ }^{15}$ Stoga su teorijski radovi koji se bave ovom pojavom gotovo su u cjelini oslonjeni na literaturu vezanu za djelatnost u kojoj se studija izvodljivosti radi, ${ }^{16}$ a definicije studije izvodljivosti raznovrsne. Ipak, suština je ista: studija izvodljivosti je poseban projekt o glavnom projektu.

14 Will Kenton, »Feasibility Study«, Investopedia, Aug 11, 2019. ukazuje na važnost odgovarajućih stakeholdera prilikom izrade studije izvodljivosti. Preuzeto s: https:/www.investopedia.com/terms/f/ feasibility-study.asp (pristupljeno 2. IV. 2020).

15 Kao ilustraciju vidjeti Prasanta Kumar Dey, »Integrated approach to project feasibility analysis: a case study«, Impact Assesment and Project Apraisal, Vol. 19, No. 3, September 2001, str. 235245.

16 Tipičan primjer je rad Ly-jin Shen, Vivivan W. Y. Tam, Leona Tam i Ying-bo-ji, »Project feasibility study: the key to successful implementation of sustainable and socially responsible construction management practice«, Journal of Cleaner Production, No. 18 (2010), str. 254-259. Samo jedna od 54 bibliografske jedinice ovoga članka, zasnovanog na istraživačkom projektu, u naslovu sadrži sintagmu »feasibility study«. Milena Redžić i Katarina Đurić, »Šta je to Studija izvodljivosti?«, DM Spot Naučno-tehnološki portal, uopštavaju iskustva IT sektora. Preuzeto s: https:/www.majkic.net/novosti/ nauka-i-tehnologija/779-sta-je-to-studija-izvodljivosti (pristupljeno 2. IV. 2020). 
Studija izvodljivosti projekta OEBiH je sistemsko multidisciplinarno ispitivanje okolnosti, uslova, pretpostavki ${ }^{17}$ i rizika, od čijeg ispunjenja u periodu trajanja projekta zavisi sposobnost ANUBiH da shodno svojoj misiji završi stvaranje i izdavanje svih tomova Opće enciklopedije Bosne i Hercegovine u skladu sa odlukama Predsjedništva ANUBiH. Ovako određena studija izvodljivosti pored projektnih sadržaja mora sadržavati i najvažnije elemente buduće Enciklopedije. Značajna anticipacija elemenata glavnog projekta ni u kom slučaju ne znači da se studija izvodljivosti može koristiti kao poslovni plan uopšte, pa ni za OEBiH..$^{18}$

Povećanje vrsta, elemenata i cijena glavnih projekata uzrokovali su gradaciju studija izvodljivosti prema složenosti. Za sada su se prema kriteriju obuhvatnosti predmeta budućeg projekta tipizirale tri vrste: studija o podobnosti, pred-studija izvodljivosti (pre-feasibility study) i studija izvodljivosti. Između njih postoje prvenstveno kvantitativne razlike. Poslovi ispitivanja najopštijih mogućnosti izrade $\mathrm{OEBiH}$ u Akademiji nauka i umjetnosti $\mathrm{BiH}$, koji imaju i osobine studije o podobnosti, obavljeni su između 2017. i 2019. godine, u fazi prethodnog postupka.

Cilj svake studije izvodljivosti je stvaranje što potpunijeg i relativno tačnog sistema naučnih i stručnih saznanja o razumnim i prihvatljivim mogućnostima pristupanja i završetka održivog poduhvata. Drugim riječima, studija izvodljivosti omogućava da se odluka o budućem projektu donese na osnovu provjerenih informacija, a ne razmišljanju baziranom na željama i intuiciji. ${ }^{19}$ Iz ovako definisanog cilja proističe i čvrsta međuzavisnost elemenata studije izvodljivosti i glavnog poduhvata. U konkretnom slučaju poduhvat je završetak izdavanja svih 10 tomova planirane Opće enciklopedije Bosne i Hercegovine.

Suštinski posmatrano, ciljevi studije izvodljivosti se mogu podijeliti na one koji pokazuju šta se mora ili treba uraditi, a šta je nužno ili poželjno spriječiti, odnosno izbjeći. Postojanje ove dvije vrste ciljeva povezuje studiju izvodljivosti sa SWOT analizom. Prvu navedenu grupu ciljeva, onu koja postavlja nužne ili korisne ishode, bitno određuju vrsta i osobine projekta na koji se studija izvodljivosti odnosi. Druga vrsta ciljeva odnosi se na savladavanje prepreka i opasnosti kojima će namjeravani projekt biti izložen. Teorija je identificirala neke opšte rizike čije neutralisanje mora biti cilj svake studije izvodljivosti. U njih spadaju naročito: izbjegavanje zdravorazumske procjene podataka, predlaganja lošeg ili neadekvatnog projekta, odlaganja

17 A. del Caño Gochi, »Continuous project feasibility study«, International fournal of Project Managment,1992, str. 166, pretpostavke naziva »hipotezama«.

18 Kenton, isto, str. 4/5, smatra poslovni plan buduće projektne organizacije oruđem za izradu studije izvodljivosti.

19 Rendy White, »The Feasibility Study: The Foundation for Success«, White Hutchinson Leisure \& Learning Group, Kansas City, MO, USA 2004, str. 2/2. Preuzeto s http://www.whitehutchinson. com/leisure/articles/where-many-feasibiity-studies -go-wrong.shtml (pristupljeno 3. X. 2020.) 
početka rada na glavnom projektu ili zakašnjenja u izvođenju glavnog projekta, odustajanja od izvođenja glavnog projekta prije njegovog završetka i neusuglašenosti glavnog projekta sa ciljevima njegovog vlasnika. ${ }^{20}$ Sažeto rečeno, ova vrsta ciljeva sprečava nosioca glavnog projekta da »slijep uđe u rizičan poduhvat «. ${ }^{21}$ Navedeni stavovi u cjelini važe i za Studiju izvodljivosti OEBiH. Bude li zaključeno da se OEBiH radi, njen kvalitet će direktno zavisiti od kvaliteta Studije izvodljivosti. ${ }^{22}$

U skladu sa metodološkim zakonitostima, anticipirana obilježja, principi i ciljevi Opće enciklopedije Bosne i Hercegovine daju osnovni putokaz Studiji izvodljivosti. To nije dovoljno. Zbog toga je Radna grupa Predsjedništva ANUBiH, kroz zaključke o organizaciji posla, posebno odredila početna načela izrade Studije izvodljivosti. Ona se najkraće mogu izraziti na sljedeći način. Najprije, »vlasnik« Studije izvodlivosti je ANUBiH kao institucija, pa će se projekt raditi na principu efikasnosti i podjele rada: opšte upravljanje - Predsjedništvo, operativno upravljanje projektom - Radna grupa Predsjedništva za OEBiH i izvršavanje poslova - Centar za leksikologiju i leksikografiju ANUBiH. Dalje, svi članovi ANUBiH, članovi naučnih odbora i istraživačkih centara će biti uključeni u poslove izrade Studije izvodljivosti, a odjeljenja će imati aktivnu naučnu i radnu ulogu u pitanjima iz svoje naučne, odnosno umjetničke oblasti. Napokon, početno će se finansiranje Studije izvodljivosti obezbijediti iz opštih sredstava ANUBiH.

Prilikom izrade bilo koje studije izvodljivosti u obzir se moraju uzeti vidljivi i skriveni, materijalni i nematerijalni, te mjerljivi i faktori koji se ne mogu kvantificirati. ${ }^{23}$ Kreativan pristup tim faktorima je ozbiljan izazov ne samo za Studiju izvodljivosti, nego i OEBiH. Zbog toga navedeni činioci zaslužuju posebnu pažnju. ${ }^{24}$ Najvažniji među njima se već sada mogu odrediti:

a) pronalaženje prave mjere između opštih pravila enciklopedistike, posebnih zahtjeva »nacionalnih« enciklopedija i suštinskih obilježja buduće $\mathrm{OEBiH}$,

20 Vidjeti Len Asprey i Michael Middleton, »Integrative Documents and Content Management: Stategies for Exploiting Enterprise Knowledge«, Chapter 8: Feasibility Study, July, 2002. Preuzeto s: https://www.igi-global.com/chapter/feasibility\%20study/24077?camid=4vl (pristupljeno 7.3. 2020).

${ }^{21}$ Kenton, isto, str. $2 / 5$.

22 Shen i dr., isto, str. 225: »Djelotvornost studije izvodljivosti će direktno prouzročiti uspjeh projekta $\ll$.

23 A del Caño, isto, str. 166.

24 Suprotan stav se nalazi kod Momin Mukherjee i Sahadev Roy, »Feasibility Studies and Important Aspect of Project Management«, International fournal of Advanced Engeneering and Management, Vol. 2, No. 4, 2017, str. 98: „Svrha studije izvodljivosti nije pružanje tačnih rješenja bilo kojeg problema koji se odnosi na plan i izgled postrojenja nego stvaranje osjećaja o njegovom željenom obimu«. 
b) nepostojanje ili neadekvatnost podataka za pojedine natuknice,

c) identifikacija kritičnih tačaka projekta koje mogu usporiti ili onemogućiti završetak poslova vezanih za $\mathrm{OEBiH}$ i previđanje alternativnih pravaca djelovanja;

d) koncipiranje sistema upravljanja rizicima koji se mogu pojaviti sve do izdavanja posljednjeg toma Enciklopedije ${ }^{25}$,

e) ažuriranje dijelova studije po potrebi, a vršenje sistemskih provjera cijele Studije izvodljivosti svakih šest mjeseci,

f) eventualne smetnje u održavanje predviđene dinamike radova,

g) sigurnost i redovitost finansiranja i

h) odnos prema subjektima suštinski zainteresiranim za OEBiH (stakeholders).

Korištenje studija izvodljivosti u svim oblastima ljudske aktivnosti dopustilo je struci i nauci da tipiziraju samo logički neizbježne i u praksi najčešće prisutne elemente strukture studije izvodljivosti: ekonomski, tehnički, operacioni i vremenski. ${ }^{26}$ Ovome se $u$ velikom broju slučajeva dodaje i pravna analiza. ${ }^{27}$ Tipizirani elementi strukture studije izvodljivosti ponekad se nazivaju »tipovima studije izvodljivosti ${ }^{28}$ Ostale opšte sastavnice zavise od uslova konkretne studije izvodljivosti ${ }^{29} \mathrm{i}$ vidljive su iz njenog sadržaja. Sa stanovišta teorije i prema rezultatima prethodnih ispitivanja stanja društva i historije enciklopedistike u BiH i ANUBiH, Studija izvodljivosti je netipična pojava smještena u nepovoljno socijalno-ekonomsko, političko i pravno okruženje. Te činjenice zahtijevaju posebnu kreativnost prilikom određivanja i konkretizacije elemenata strukture sadržaja Studije izvodliivosti.

25 Vidjeti A. del Caño, isto, str. 167-168.

${ }^{26} \Perp$ What is a feasibility study? Definition and examples«, str. 2/5. Preuzeto $s$ http://marketbusinessnews.com/finansial gosary/feasibility study/ (pristupljeno 3. V. 2020); Kathy Castle, »Feasibility Study in Project Management«, str. 1 i 2-4. Preuzeto s https://www.projectcubicle.com/feasibility-study-inproject-management/ (pristupljeno 4. V. 2020).

${ }_{27}$ Castle, isto, str. 2; Mukherjee i Roy, isto, str. 98; Redžić i Đurić, isto, str. 3/3.

$28 »$ Feasibility Study: An assessment of the practicality of a proposed project/plan«, Corporate Finance Institute. Preuzeto s: https://corporatefinanceinstitute.com/resoruces/knowledge/other/feasibility-study/; (pristupljeno 2. IV. 2020).

29 A. del Caño, isto, str. 166, naziva ih »hipotezama« i navodi: tržište, ekonomsko, socijalno i političko okruženje, dostupnost resursa itd. Kumar Day u citiranom djelu zahtijeva posebnu analizu uticaja naftovoda na okoliš, a Shen et al. u radu posvećenom velikim projektima urbanog razvoja insistiraju na tome da studije izvodljivosti treba da utvrde standarde društvene odgovornosti izvođača radova. 


\section{Pravna i etička izvodljivost Projekta OEBiH}

Važnost stvaranja opće enciklopedije za društvo je tolika da po pravilu postoji izričit pravni osnov za direktnu podršku cijele države tom poduhvatu. Ovu tvrdnje potkrepljuje uporedni pregled pravnih sistema zemalja u našem okruženju. U njima ne postoje ustavno-pravne prepreke za angažman države pri izradi opće enciklopedije, pa se ovaj izdavački poduhvat uređuje zakonima na različite načine. ${ }^{30}$ Iz pregleda zakonodavstva susjednih zemalja mogu se izvući neki opšti zaključci relevantni i za BiH. Prvi je da sve zemlje okruženja stvaranje državnih enciklopedija smatraju poslom od opšteg, pa stoga i od javnog interesa. Činjenica da su svi zvanični jezici u susjednim državama u ogromnoj mjeri srodni nije uticala na stav o potrebi izrade sopstvenih enciklopedija. Drugi zaključak je da se javni interes ispoljava i štiti na veoma slične načine: zakonskim regulisanjem obaveze izrade državne, tj. nacionalne enciklopedije i određivanjem pravnih lica čiji je to zadatak, te aktivnom ulogom države $u$ procesu finansiranja i izrade nacionalne enciklopedije.

Prema dejtonskom Ustavu ${ }^{31}$, obrazovanje, nauka i kultura, uključujući i enciklopedistiku, spadaju u nadležnost entiteta Republika Srpska i kantona u entitetu Federacija Bosne i Hercegovine. ${ }^{32}$ Budući da nisu zaključeni sporazumi entiteta o prenošenju nadležnosti za oblast obrazovanja, nauke i kulture, uključujući izradu OEBiH, na državu Bosnu i Hercegovinu, ${ }^{33}$ izričit i neposredan konstitucionalni osnov za angažman države Bosne i Hercegovine u projektu OEBiH ne postoji. Ta činjenica daje pravnom osnovu izrade Enciklopedije kao državnog projekta prejudicijelni karakter, a juridičkim pitanjima prvo mjesto u strukturi Studiji izvodljivosti.

Postojanje posrednog pravnog osnova za izradu $\mathrm{OEBiH}$ na nivou države Bosne i Hercegovine se mora utvrđivati tumačenjem principa i teksta njenog Ustava. Preambula i odredbe čl. I.2 Ustava pokazuju da je Bosna i Hercegovina demokratske i pravna država zasnovana na principima slobode i potpunog poštivanja ljudskih prava. Stoga bi pokušaji direktnog ili indirektnog zakonskog sprečavanja ili ometanja izdavanja OEBiH istovremeno bili povreda prava ANUBiH i drugih subjekata koji smatraju da im je ovakva publikacija potrebna za ostvarivanje konstitucionalno i konvencijski zajamčenih ljudskih prava.

30 Vidjeti čl. 17, st. 1, tačka 9 Zakona o Crnogorskoj akademiji nauka i umjetnosti (Službeni list Crne Gore, broj 14 od 7. 3. 2012); Narodne novine Republike Hrvatske, broj 96/03 i 190/03 i Službeni glasnik Republike Srbije, broj 110/05.

31 Čl.III.1. Ustava Bosne i Hercegovine

32 Vidjeti čl. 68, alineja 8) Ustava Republike Srpske. Prma članu 4. Ustava Federacije Bosne i Hercegovine: »Kantoni imaju sve nadležnosti koje nisu izričito povjerene federalnoj vlasti...«. U tačkama b) i c) ovog člana se izričito spominju obrazovanje i kultura.

33 Ovakav sporazum je moguć na osnovu čl. III. 5. Ustava Bosne i Hercegovine. 
Posredan zakonski osnov također postoji. Još je čl. 2. »Zakona o Naučnom društvu Bosne i Hercegovine « ${ }^{34}$ naložio Društvu »da doprinosi razvoju nauke, da izučava prirodna bogatstva i proizvodne snage $\mathrm{BiH}$ i doprinosi njihovom racionalnom iskorištavanju...«. Zakon o Akademiji nauka i umjetnosti Bosne i Hercegovine ${ }^{35}$ istu je misiju izrazio pregnantnije: unapređivanje nauke i umjetnosti i razvijanje društva. Ona je ostala nepromijenjena do danas. Kada se izjava o misiji ANUBiH uporedi sa definicijom opće enciklopedije, postaje jasno da izrada OEBiH ulazi u samu srž djelovanja Akademije i da Enciklopedija predstavlja, magnum in parvo, njenu misiju.

Krajnji zaključak se nameće sami od sebe! Ustavni i zakonski materijalno-pravni osnov za izdavanje $\mathrm{OEBiH}$ nisu izričito formulisani, ali se mogu nesumnjivo utvrditi iz niza ustavnih i zakonskih načela i odredbi.

Utvrđivanje etičkog osnova projekta ANUBiH koji bi rezultirao OEBiH daleko je lakše. Opšti pojam enciklopedije, anticipirana suštinska obilježja i utvrđeni principi OEBiH jasno pokazuju da usvojeni koncept OEBiH može izdržati test »dobroga«, bez obzira na to koja je etička teorija uzeta kao mjerodavna. Na praktičnoj razini to znači da se autori i urednici OEBiH moraju se pridržavati zakonskog principa »etičnosti naučnika i istraživača «. ${ }^{36}$ Pretpostavka da će oni tako postupati i činjenica da je $\mathrm{OEBiH}$ a priori »dobra« ne znači da će tvorci Enciklopedije biti pošteđeni izuzetno teških etičkih dilema. Najočiglednije se mogu već sad predvidjeti: odnos prema postojećim enciklopedijama u BiH, okruženju i svijetu, odabir kriterija važnosti pojedinih pitanja koja će biti ili neće biti uvrštena u enciklopediju, omjer opšteg i partikularnog, selekcija odrednica, mjerila izbora autora i recenzenata, zaštita autorskih prava, ${ }^{37}$ pristup društveno najosjetljivijim odrednicama, odnos prema itd. Već u ovoj fazi priprema jasno je da će etička pitanja u Studiji izvodljivosti zahtijevati posebnu obradu i da će ANUBiH morati obezbijediti stalni etički konzalting za sve učesnike u projektu. Pored toga što postoji kao samostalna sastavnica projekta izvodljivosti OEBiH, etička prihvatlijivost pojedinih elemenata cijelog projekta prožima i sve druge parcijalne »studije izvodljivosti«, a socio-političku posebno.

34 Službeni list NR BiH, broj 14/51.

35 Službeni list SR BiH, broj 22/66. Vidjeti i Službeni list SR BiH, broj 40/75 i 33/81. Položaj ANU$\mathrm{BiH}$ je posljednji put zakonski regulisan regulisan u Službenom listu R BiH, broj 15/94. Odluka Ustavnog suda Bosne i Hercegovine AP-1679/17 od 10.11.2020.g (Službeni glasnik BiH 76/12) je po apelaciji ANU$\mathrm{BiH}$ potvrdila status Akademije kao institucije Bosne i Hercegovine.

36 Vidjeti čl. 3 Okvirnog zakona o osnovama naučno-istraživačke djelatnosti i koordinaciji unutrašnje i međunarodne naučno-istraživačke saradnje Bosne i Hercegovine (Službeni glasnik BiH, broj 59/03) (dalje: OZNID).

37 Pezo Vladimir: »Autorsko pravo u enciklopedičkom i leksikografskom radu«, Radovi Leksikografskoga zavoda Miroslav Krleža, knj. 10, Zagreb, 2001., str. 73 naročito. 


\section{Socio-politička izvodljivost Projekta OEBiH}

Šire shvaćena socio-politička izvodljivost obuhvata postojeće i predvidljive društvene okolnosti od kojih zavisi odluka o (ne)pristupanju izradi OEBiH. Relevantne okolnosti mogu imati makro i mikro, objektivni i subjektivni karakter. U studijama izvodljivosti dugotrajnih projekata korektno je zadržati se pretežno na objektivnim makroelementima socio-političkog okruženja. Političke potrebe i želje različitih subjekata nisu uključene u socio-političku izvodljivost, mada mogu uticati na nju.

Ovdje ćemo se zadržati na objektivnim sociološkim i političkim faktorima koji determiniraju sudbinu cijelog poduhvata. Oni se sve češće nalaze i u čisto ekonomskim studijama izvodljivosti i u radovima koji su im posvećeni. ${ }^{38} \mathrm{Za}$ vrstu projekta kakav je OEBiH čini se da socio-politički faktori u donošenju odluka imaju istu, ako ne i veću specifičnu težinu od nekih drugih uslova, organizacionih na primjer. Zbog toga pri izradi ove Studije izvodljivosti uvijek treba imati na umu memento koji je, makar i u zagradi, naveo A. del. Caño: »ako uslovi izvodljivosti nisu kompatibilni sa okruženjem, projekt mora biti napušten « ${ }^{39}$

U objektivne makro sociološke elemente Studije izvodliivosti, koji su načelno jednaki i u ostalim slijednicama bivše države, spadaju naročito:

a) promjene društveno-ekonomskog i političkog uređenja prouzrokovane prelaskom sa društvene na dominaciju privatne svojine i tržišne privrede, sa jednopartijskog sistema na višestranačku demokratiju;

b) afirmacija nacionalnog nauštrb građanskog pristupa organizaciji države i društva, uključujući i stvaranje teritorijalno omeđenih nacionalnih političkih i ekonomskih oligarhija. ${ }^{40} \mathrm{U}$ oblasti enciklopedistike, ovaj element se manifestuje kao pojava dvije nove, u suštini etničke enciklopedije unutar države Bosne i Hercegovine;

c) nova politička i ekonomska geografija na prostoru bivše zajedničke države. Ona, između ostalog, rezultira i pojavama dvije nove državne enciklopedije relevantne za BiH - u R. Hrvatskoj i R. Srbiji;

38 Vidjeti npr. Shen i dr., isto str. 256 i 258, koji navode da su analizirali 18 ekonomskih, devet socijalnih i osam okolišnih performansi svakog projekta. Kumar Day, isto, str. 237, opravdava usvajanje metoda »analitičkog hijerarhijskog procesa (AHP)« time što on zahtijeva »aktivnu participaciju donosilaca odluka u postizanju sporazuma...«.

39 A. del Caño isto, str. 165.

40 Vidjeti Mirko Pejanović, »Promjene etničke strukture opština u Bosni i Hercegovini prema popisu stanovništva 2013. godine«, u: Cvitković, Ivan (ur.), »Demografske i etničke promjene u BiH« ANUBiH, Sarajevo 2017, str. 70-93. Posebno su relevantna izlaganja na str. 84-88. 
d) stupanje $\mathrm{BiH}$ u procese regionalnih i euroatlantskih integracija. Novi strategijski ciljevi zahtijevaju prilagođavanje cjelokupnog društva široj regulativi, zajedničkim standardima djelovanja i kulturološkim obrascima koji nisu utemeljeni samo u jednoj etniji ili državi. ${ }^{41}$ Proces prilagođavanja nije jednosmjeran i jednostran, ali je $\mathrm{BiH}$ u njemu objektivno slabija strana. Kako uključivanje u međunarodne integracije ne bi za državu, etnije i pojedinca značilo nestanak, nego poželjnu modifikaciju identiteta, nužno je znati šta se u te procese unosi. OEBiH bi trebala pružiti objektivan i sažet odgovor i na taj zahtjev;

e) postepeno ali konstantno uključivanje Bosne i Hercegovine u globalizacijske procese. $^{42}$

Pored zajedničkih, u slučaju Bosne i Hercegovine postoje i specifični objektivni makro sociološki elementi koji djeluju na mogućnost izrade Enciklopedije. Među njima treba izdvojiti naročito:

a) ratni gubici fizičkog i ljudskog kapitala koji su višestruko veći nego u drugim državama nastalim disolucijom SFRJ

b) 25 godina trajanja izuzetno jakog sindroma post-ratnog društva

c) nedovoljna integrisanost bosanskohercegovačkog društva na ustavnoj, političkoj i ekonomskoj, osnovi

d) tendencija apsolutizacije etničkog $\operatorname{principa}^{43}$ i sa time povezane blokade političke i državne strukture društva

e) sistemska korupcija, uključujući i političku, koja je rezultirala de facto klijentističkim mentalitetom ${ }^{44}$

41 Vidjeti, na primjer, »Odgovori Bosne i Hercegovine na pitanja iz Upitnika EK«, Direkcija za evropske integracije. Preuzeto s: http://www.dei.gov.ba/dei/direkcija/sektor_strategija/Upitnik/odgovoriupitnik/Archive.aspx?langTag=bs-BA\&template_id=120\&pageIndex=1; »Odgovori na dodatna pitanja iz upitnika: Poglavlje 25 Nauka i istraživanje«, Direkcija za evropske integracije BiH. Preuzeto s: http:// www.dei.gov.ba/dei/direkcija/sektor_strategija/Upitnik/dodatnapitanja/Archive.aspx?langTag=bsBA\&pageIndex $=1$ (pristupljeno 23. III. 2020).

42 Bosna i Hercegovina je ratifikovala The Energy Charter Treaty i povezane dokumente 2000. godine (Odluka o ratifikaciji ugovor o energetskoj povelji, Službeni glasnik BiH, broj 31/00). Pregovori o pristupanju svjetskoj trgovinskoj organizaciji (WTO) su u toku, vidjeti: World Trade Organization Ascessions Newsletter, No. 98, January/February 2020. Preuzeto s: https://www.wto.org/english/thewto_e/ acc_e/nl_e/2020_01_acc_newsletter_e.pdf (pristupljeno 3. III. 2020).

43 Ekstreman dokaz za ovu tvrdnju su posebne škole za djecu različitih etnija pod jednim krovom. Vidjeti: »Mapa: Dvije škole pod jednim krovom u BiH«. Preuzeto s: https://www.diskriminacija.ba/ teme/mapa-dvije-\%C5\%Alkole-pod-jednim-krovom-u-bih. (pristupljeno 22.III.2020.)

44 Vidjeti »Godišnji izvještaj 2017«, Transparency International Bosnia and Herzegovina, Banja Luka, februar 2018. Preuzeto s: https://ti-bih.org/wp-content/uploads/2018/04/TIBIH-Godisnji-Izvestaj- 
f) intenzivna depopulacija $u$ cijelom post-ratnom periodu ${ }^{45}$

g) društveno neuspješna privatizacija, u praksi dominantno etnička i $»$ tajkunska $\aleph^{46}$

h) relativno siromašno društvo ${ }^{47}$ koje se još uvijek razvija na bazi efikasnije eksploatacije resursa, a ne na znanju kao faktoru stvaranja nove dodatne vrijednosti. ${ }^{48}$

Uticaj pojedinog makro sociološkog i političkog elementa i njihovo ukupno djejstvo na mogućnost ANUBiH da ostvari projekt $\mathrm{OEBiH}$ treba posebno analizirati. S obzirom na to da svaki element ima dinamičan karakter i da svaki djeluje povezano sa drugim, preispitivanje mora biti kontinuirano i multivarijantno. Ako se ostave po strani navedeni metodološki postulati, može se zaključiti da trenutno preliminarna analiza ne daje jasan odgovor na pitanje o sociopolitičkoj izvodljivosti projekta OEBiH.

U prilog izvodljivosti djeluju sljedeći zajednički elementi: suštinske promjene društveno-političkog sistema u zemlji, procesi regionalne integracije i uključivanje $u$ globalizaciju. Zajednički elementi koji mogu djelovati u prilog izradi OEBiH ili protiv nje su: iznalaženje balansa između nacionalnog i građanskog principa organizacije društva, pozicioniranje bosanskohercegovačke enciklopedistike između hrvatske i srbijanske i mogući uticaj OEBiH na jačanje zajedničke kulture unutar našeg društva i države. Od opštih elemenata, protiv teze o izvodljivosti OEBiH mogu se

Web-FIN.pdf (pristupljeno 24. III. 2020.).

${ }_{45}$ Za ratni i period do 2013. godine vidjeti radove Mirza Emirhafizović i Hasan Zolić, Dobna struktura i reprodukcija stanovništva Bosne i Hercegovine, u: Cvitković, Ivan (ur.), »Demografske i etničke promjene u $\mathrm{BiH} \ll$, ANUBiH, Sarajevo 2017, str. 12-18. Za nove tendencije iseljavanja stanovništva iz $\mathrm{BiH}$ vidjeti Muris Čičić (ur.), »Studija o migracijama - Bosna i Hercegovina«, ANUBiH - Centar za sistemska istraživanja, Knjiga 4, Sarajevo 2019, posebno str. 47-69.

${ }^{46}$ Boris Divjak i Aleksandra Martinović (ur.), »Privatizacija državnog kapitala u Bosni i Hercegovini«, Transparency International Bosnia and Herzegovina, Banja Luka, 2009, str. 26-40: »Ishod privatizacije u Bosni i Hercegovini«.

47 Po nominalnom nacionalnom dohotku BiH se 2019. g. nalazila na 37. mjestu u Evropi i 114. mjestu u svijetu. BDP mjeren prema kupovnoj snazi (PPP) daje neznatno drukčiju sliku: u Evropi BiH zauzima 34. a u svijetu 111. mjesto. (Vidjeti: »List of European countries by GDP«, Statistics Times, www.statisticstimes.com/economy/european-countries) (pristupljeno 24. III. 2020). Za finansijsku relativizaciju ove tvrdnje vidjeti rad dopisnog člana ANUBiH, prof. dr. Fikreta Čauševića: »Ekonomski položaj zemalja Zapadnog Balkana u procesu finansijske globalizacije 2000-2016.«, 8. Međunarodna naučnostručna konferencija Razvoj poslovanja 2018: Ekonomski izazovi zemalja u tranziciji, 14 i 15. novembar 2018., »Zbornik radova«, urednik Alaudin Brkić, Zenica 2019, str. 45-66.

${ }^{48}$ Claus Schwab, »The Global Competitiveness Report 2017-2018«, World Economic Forum, str. 320, Tabela 2 svrstava $\mathrm{BiH}$ u zemlje čiju ekonomiju dominantno pokreće efikasnost iskorištavanja postojećih resursa. 
navesti: afirmacija nacionalnog i savremena politička geografija, uključujući realno stanje odnosa $\mathrm{BiH}$ sa susjedima. Svi posebni elementi karakteristični za naše društvo također upućuju na negativan odgovor na pitanje o mogućnosti izrade $\mathrm{OEBiH}$.

Da zaključimo! Na nivou kvantitativne analize elemenata, odgovor je negativan: projekt $\mathrm{OEBiH}$ ne treba počinjati jer dominiraju socio-politički elementi koji ne jamče njegov uspješan završetak. Kvalitativna analiza zasnovana na kriteriju strategijske važnosti pojedinih elemenata i snazi sinergijskog djelovanja razvojnih društvenih i političkih potreba daje odgovor u prilog izvodljivosti projekta OEBiH. Time se zauzimanje konačnog stava o sudbini projekta OEBiH odlaže do ispitivanja ostalih osnova izvodljivosti.

\section{Ekonomska izvodljivost Projekta OEBiH}

Studija izvodljivosti je zaseban projekt koji se radi prije glavnog projekta. Mogućnosti iskorištavanja elemenata studije izvodljivosti u izradi glavnog projekta i njegovoj eventualnoj izvedbi ne utiču na ovu tvrdnju. Samostalnost studije izvodljivosti zahtijeva da se njena cijena posebno izračunava, a troškovi odvojeno finansiraju. U dobro uređenim privrednim granama orijentacioni trošak studije izvodljivosti u pravilu se utvrđuje standardiziranim procentom vrijednosti glavnog projekta. ${ }^{49}$ Studija izvodljivosti i glavni projekt $\mathrm{OEBiH}$ se po više mjerila ne uklapaju u model tipiziranih aktivnosti, pa se njeno i koštanje mora posebno kalkulisati. ${ }^{50}$

Za sada je izrada Studije izvodljivosti OEBiH zasnovana na besplatnom radu članova ANUBiH, posebno onih koji su uključeni u Radnu grupu. Materijalni troškovi ove faze rada se pokrivaju iz opštih sredstava ANUBiH. Ovakav način djelovanja može dati rezultate samo privremeno. Kada se sagledaju svi glavni elementi Studije izvodljivosti, neophodno će biti izračunati cijenu njene izrade, uz uvažavanje opštih kriterija struke i specijalnih zahtjeva ANUBiH. Sljedeći korak mora biti obezbjeđenje potrebnih finansijskih sredstava, polazeći od postojećih kontakata sa Fondacijom »Pravda za BiH«. Druga mogućnost je prijavljivanje Studije izvodljivosti na javne pozive federalnih ministarstava nadležnih za nauku i kulturu radi (su)finansiranja ili traženje posebnih grantova za ovaj posao.

Fokalna tačka svih studija izvodljivosti i svih pojedinačnih elemenata studije je ekonomska izvodljivost. Ključni element ekonomske izvodljivosti je osiguravanje dovoljno novčanih sredstava za završetak i eventualno uspješnu eksploataciju projek-

49 White, isto, str. 1/2: »Fizibiliti studije obično ne koštaju više od 1\% do 1,5\% ukupnih troškova FEC«, tj. troškova izgradnje lokalnih centara za porodičnu zabavu.

50 U pripremnoj fazi studije izvodljivosti jedna ponuda koju je dobila ANUBiH je glasila na cca. 125.000,00 KM. 
ta. Ipak, svi elementi ekonomske kalkulacije izvodljivosti ne mogu se reducirati samo na novac.

$\mathrm{Na}$ ekonomsku izvodljivost $\mathrm{OEBiH}$ bitno će uticati najprije činjenica da je projekt zamišljen kao neprofitan. Zbog toga će neki standardni elementi studije izvodljivosti, na primjer početna kalkulacija maloprodajne cijene i profitabilnost, biti značajno modificirani ili neće postojati. Druga osobina projekta koja ima značajne implikacije na ekonomsku izvodljivost $\mathrm{OEBiH}$ je njegova dugoročnost. Preliminarno je izračunato da sve faze projekta treba da budu završene 18 godina. ${ }^{51} \mathrm{U}$ cijelom razdoblju treba osigurati neprekidno dobivanje tačnih informacija o troškovima i najnovijim finansijskim pokazateljima. ${ }^{52}$ Oni će sigurno nametati kontinuirani rebalans budžeta $\mathrm{OEBiH}$, a time i zahtjeva ANUBiH prema finansijerima - državi prvenstveno. Treći faktor ekonomske izvodljivosti su veličina i cijena projekta $\mathrm{OEBiH}$. »Orijentaciona kalkulacija potrebnih sredstava « ${ }^{53}$ iznosi $30.000 .000 \mathrm{KM}$ ili 1.500.000 KM godišnje u periodu od dvije decenije. To je približno $250.000 \mathrm{KM}$ više od granta koji je u 2019. g. Kanton Sarajevo dao ANUBiH za njeno redovno funkcionisanje.

Prvi zaključak na osnovu sva tri obilježja projekta je da država mora preuzeti finansiranje OEBiH. Najpoželjnije bi bilo da to učini Bosna i Hercegovina. S obzirom na veličinu sume i sadašnju političku konstelaciju, realno je pretpostaviti da će više nivoa državne vlasti učestvovati u finansiranju ovog projekta od opšteg interesa. A to znači da bi se budžetska linija za OEBiH morala naći u zakonu u budžetu svake političko-teritorijalne zajednice koja bude podržavala projekt OEBiH. Državno budžetsko finansiranje ne isključuje doprinos ostalih subjekata izdavanju ovog značajnog naslova. ${ }^{54}$

Drugi zaključak je da sva ispitana obilježja ukazuju na brojne inherentne rizike projekta OEBiH u domenu finansiranja. Najočigledniji su: odbijanje pojedinih nivoa državne vlasti da se dugoročno obavežu na (su)finansiranje OEBiH, prestanak finansiranja ili umanjenje obećanih budžetskih iznosa uslijed objektivnih okolnosti ${ }^{55}$ ili kao polugu uticaja na redakciju $\mathrm{OEBiH}$ i cijelu $\mathrm{ANUBiH}$, kašnjenja u isplati

${ }^{51}$ Vidjeti Odsjek 9 ovog rada.

${ }^{52}$ M. Mukherjee i S. Roy, isto, str. 99.

53 Kalkulaciju je u martu 2020. godine sačinio generalni sekretar ANUBiH akademik Zijo Pašić na bazi ranijih izračuna troškova izdavanja leksikona u ANUBiH.

${ }^{54}$ Čl. 11, st. 2 Zakona o Enciklopediji Republike Srpske glasi: »Akademija će sa lokalnim zajednicama, privrednim i ostalim zainteresiranim subjektima ugovorom regulisati prava i obaveze u izradi Enciklopedije."

55 Ovaj tekst se piše u vrijeme obavezne izolacije radi sprečavanja djelovanja COVID-19. Ekonomske posljedice pandemije još su nepredvidljive. Pojava sličnih događaja nije isključena ni u budućnosti. 
budžetskih sredstava, pritisak na nedržavne subjekte koji sufinansiraju izdavanje OEBiH itd.

\section{Kadrovi kao faktor izvodljivosti Projekta OEBiH}

Nakon obezbjeđenja ekonomskih uslova, finansijskih sredstava naročito, angažovanje kritične mase odgovarajućih stručnih kadrova je drugi ključ uspjeha svakog projekta. Usprkos tome, pregledana literatura o studiji izvodljivosti se ne bavi posebno ovim pitanjem..$^{56}$ Iz toga se može zaključiti da su potrebni stručnjaci uvijek dostupni ili da se u projekt ne ulazi dok njihova saradnja nije obezbijeđena u potrebnoj mjeri. Historijat enciklopedistike i broj istraživača $\mathrm{u} \mathrm{BiH}^{57}$ pokazuju da neće biti lako okupiti potreban intelektualni potencijal za uspješan završetak OEBiH. Zato Studija izvodljivosti mora kadrovima kao »kritičnom parametru« $\aleph^{58}$ posvetiti posebnu pažnju.

OEBiH je »vlasništvo« cijele ANUBiH, pa je članstvo Akademije primarni kadrovski resurs za ovaj projekt. U 2020. g. ukupan broj svih vrsta članova je 84, od toga četiri člana koji su po obrazovanju, pozivu i zvanjima posvećeni (i) pitanjima enciklopedistike. Očite su dvije stvari. Najprije, za projekt OEBiH će biti neophodno trajno angažovanje saradnike u naučnim i stručnim zvanjima iz oblasti enciklopedistike. I drugo, dosadašnja praksa da su članovi radnog sastava nosioci najvećeg dijela aktivnosti mora pri izradi OEBiH biti napuštena. S obzirom da Predsjedništvo na prijedlog odjeljenja i centara imenuje članove naučnih tijela $\mathrm{ANUBiH}$, drugi veliki »bazen" kadrova za OEBiH nalazi se u odborima i centrima odjeljenja. Početkom 2020. godine u ANUBiH je postojalo 17 odbora odjeljenja sa ukupno 232 člana. U šest centara je bilo angažirano 93 člana. Dakle, oko Akademije je već okupljeno 325 naučnika iz širokog spektra naučnih i umjetničkih disciplina. Sinergijsko djelovanje broja saradnika i pokrivenosti naučnih oblasti može veoma povoljno uticati na sposobnost ANUBiH da završi izdavanje svih tomova Enciklopedije. Uslov za to je angažiranje dodatnog odgovarajućeg stručnog administrativnog kadra.

56 Do sada citirani radovi se ne osvrću na kadrovsku izvodljivost projekta. A del Caño, isto, str. 166, navodi, primjera radi, $21 »$ skriveni faktor« koji može da ugrozi uspjeh projekta. Nijedan od njih se ne odnosi na kadrove.

57 Vidjeti »Odgovori na dodatna pitanja iz upitnika: Poglavlje 25 Nauka i istraživanje«, Direkcija za evropske integracije $\mathrm{BiH}$, str. 17, tabele 1-4. Prema tim odgovorima, u 2016. godini u BiH je bilo 1942 lica zaposlena na poslovima istraživača. U radnom odnosu na puno ili radno vrijeme kraće od punog angažirano je 1367 straživača.

58 A. del Caño, isto, str. 166: »...fizibiliti studija mora definisati kritične parametre tako da se oni mogu pratiti i kontrolisati na intenzivan i specifičan način tokom cijelog života projekta.« 
Već sada je izvjesno da kadrovi okupljeni u ANUBiH i oko nje ne mogu sami uraditi sve enciklopedijske poslove i natuknice. Zbog toga će se prvenstveno urednici struka potruditi da sa univerziteta u $\mathrm{BiH}$, ali i van njenih granica, angažuju stručnjake i autore koji nedostaju. U istu svrhu se može iskoristiti postojanje devet bilateralnih sporazuma o saradnji sa drugim nacionalnim akademijama, članstvo ANUBiH u osam međunarodnih asocijacija, ${ }^{59}$ sporazumi o saradnji sa brojnim univerzitetima u $\mathrm{BiH}$ i pridruženo članstvo ANUBiH u Rektorskoj konferenciji / zboru Bosne i Hercegovine.

Iz prethodnih analiza neki se zaključci nameću sami. Najprije, u ANUBiH postoje upravljački kadrovi potrebni za izradu OEBiH. Isto se može reći i za rukovođenje, s tim da je jedna dopuna nužna. Ova funkcija mora biti ojačana osobama sa dubokim specijalističkim poznavanjem enciklopedistike i sa radnim iskustvom u ovoj disciplini. Dalje, članstvo ANUBiH pojačano članovima odbora i centara te univerzitetskim nastavnicima čini dovoljan intelektualni potencijal za upuštanje u složen poduhvat stvaranja nove enciklopedije. Treće, najveći kadrovski problem će predstavljati stalno radno uključivanje naučnih savjetnika i naučnih saradnika iz oblasti enciklopedistike u projektni tim ANUBiH. Angažman stručnih saradnika će biti veći finansijski nego kadrovski problem. Napokon, kadrovska izvodljivost OEBiH je izložena brojnim rizicima za čije otklanjanje ili ublažavanje dugoročnost projekta može, ali ne mora biti olakšavajuća okolnost. To su naročito: nepostojanje eksperata za pojedina pitanja ni u zemlji ni u okruženju, odbijanje ili prestanak saradnje i odlaganje izvršenja posla iz objektivnih ili subjektivnih razloga.

\section{Organizaciona izvodljivost Projekta OEBiH}

Organizaciona izvodljivost je poseban dio studije izvodljivosti kada glavni projekt ne može biti pokrenut niti uspješno funkcionisati ukoliko »vlasnik» projekta ne izvrši neophodne formalne organizacione zahvate. Oni se mogu izvesti unutar postojećeg subjekta ili stvaranjem nove projektne organizacija sa svojstvom pravnog lica ili bez tog svojstva. Ako priroda posla zahtijeva, uz organizacionu se vežu operativna, pravna i menadžerska pitanja. ${ }^{60}$ To će biti slučaj i sa projektom $\mathrm{OEBiH}$.

Neka organizaciona rješenja rada na projektu OEBiH su razmatrana već u prethodnom postupku, samostalno ili zajedno sa pitanjima vezanim za izradu Studije izvodljivosti. ${ }^{61}$ Prvo relativno cjelovito viđenje organizacije rada na $\mathrm{OEBiH}$ dao je

59 Za navedene podatke o ANUBiH vidjeti njenu zvaničnu stranicu: www.anubih.ba (pristupljeno 26. III. 2020).

60 Vidjeti Kenton, isto, str. 4/5, na primjer.

61 Odluka Predsjedništva ANUBiH od 26. XI. 2019. godine o organizaciji rada na Općoj enciklopediji Bosne i Hercegovine. 
domaći član ANUBiH prof. dr. sci. Ivan Markešić u »Materijalu za Radnu grupu za izradu Studije izvodljivosti. ${ }^{62}$ Njegova osnovna ideja je bila povezivanje upravljačkih i radnih ovlaštenja organa Akademije sa organima projekta Enciklopedije. Uz manja prilagođavanja opštim aktima ANUBiH ovaj prilog je postao ključni organizacioni dokument. ${ }^{63}$ Njegova trenutno najvažnija dopuna je uvođenje funkcije glavnog savjetnika predsjednika Radne grupe za OEBiH..$^{64}$ Napokon, podjela poslova i odgovornosti u izradi Studije izvodljivosti između organa i tijela ANUBiH je usvojena na prvom sastanku Radne grupe. ${ }^{65} \mathrm{~S}$ obzirom na to da se radi o statutarnoj materiji, ova odluka o nadležnostima se mutatis mutandis može primijeniti i na izradu $\mathrm{OEBiH}$. Prikaz potrebne organizacije rada na opštoj enciklopediji Bosne i Hercegovine dajemo šemom br. 1.

Šema br. 1. Organizacija rada na projektu ANUBiH Opća enciklopedija Bosne i Hercegovine

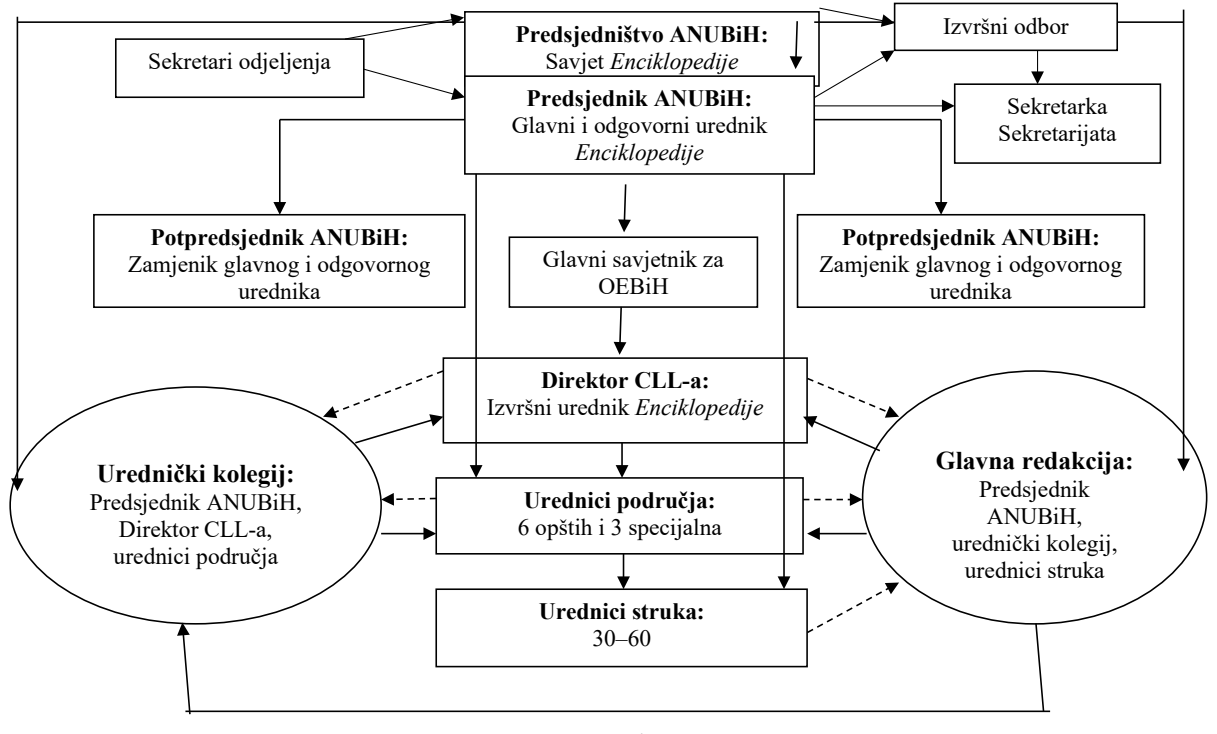

Legenda:

- Pune strelice označavaju linije odlučivanja

- Isprekidane strelice označavaju ulazak u sastav radnih tijela

62 Ivan Markešić, »Opća enciklopedija Bosne i Hercegovine - Uredništvo, organizacija, upute - Akademija nauka Bosne i Hercegovine«, Zagreb, 9. srpnja 2019.

63 Tačka 5. Zaključaka prvog sastanka Radne grupe za izradu Studije izvodljivosti Opće enciklopedije Bosne i Hercegovine, broj 04 - 09-2 - 6-5/20 od 27. I. 2020. godine.

64 Odluka 59. sjednice Izvršnog odbora od 17. II. 2020. godine, br. 04 - 09-2 - 6-7/20 o imenovanju savjetnika predsjednika ANUBiH na projektu izrade Opće Enciklopedije BiH.

65 Zaključak br. 3:»Usvaja se dokument 'Pregled faza za izradu Studije izvodljivosti Opće enciklopedije Bosne i Hercegovine«, Radna grupa ANUBiH, broj 04-09-2 - 6-5/20 (autor akademik Miloš Trifković). 
Dosadašnja ispitivanja organizacione izvodljivosti projekta $\mathrm{OEBiH}$ potvrđuju hipotezu da ANUBiH sa Centrom za leksikologiju i leksikografiju kao operativnim izvršiocem može započeti i uspješno završiti izdavanje Enciklopedije. Ipak, uzimajući u obzir obilježja i okolnosti projekta, navedenu tvrdnju je potrebno primiti sa oprezom. Zbog toga su već ispitana i moguća alternativna organizaciona rješenja podobna da umanje štetne posljedice negativnog sinergijskog djelovanja unutrašnjih i spoljnih okolnosti projekta na njegov uspješan završetak.

\section{Vrijeme kao faktor izvodljivosti Projekta OEBiH}

Vrijeme je mjera i faktor svake ljudske aktivnosti. Iz do sada citiranih izvora o studijama izvodljivosti vidljivo je da značaj vremena za izvodljivost projekta zavisi najprije od njegovog predmeta. U projektu čiji početak, trajanje, napuštanje ili gašenje značajno utiču na odluku o njegovoj sudbini, vremenska izvodljivost ili »red vožnje« (Scheduling Feasibility) posebno se ispituje. To se čini direktno, ili kroz temporalno preciziranje drugih elemenata konkretne studije izvodljivosti. ${ }^{66}$

Vremenska izvodljivost ima više pojavnih oblika: vrijeme pripreme, period izgradnje projekta, vrijeme operativnosti projekta, vrijeme efektivne eksploatacije, najprofitabilniji period projekta itd. Zbog toga se kao opšta može prihvatiti definicija po kojoj je »vremenska izvodljivost mjera razumnosti trajanja projekta« ${ }^{67}$ Razumnost trajanja projekta, pak, zavisi prvenstveno od faktičkih osobina projekta i specifičnih interesa njegovog »vlasnika«, što zahtijeva individualnu procjenu vremenske izvodljivosti svakog projekta.

Polaznu osnovu za utvrđivanje vremenske izvodljivosti Projekta OEBiH čini već usvojeni materijal »Pregled faza za izradu studije izvodliivosti Opće enciklopedije Bosne $i$ Hercegovine«. ${ }^{68}$ Prethodni postupak je trajao tri godine, od 2017. do kraja 2019. godine. On je završen odlukom Predsjedništva o formiranju Radne grupe za izradu Studije izvodljivosti. ${ }^{69}$ Zaključcima Radne grupe za izradu Studije izvodljivosti OEBiH od 3. 2. 2020. g. započela je druga velika faza projekta. Predviđeno je da ona traje pune tri godine. $\mathrm{Na}$ osnovu iskustvenog pravila po kome je planiranje projekta

66 Shen i dr., Project feasibility study, 2010., str. 257, kao atribute fizibiliti studija u oblasti građevinarstva uzimaju troškove i profit u životnom ciklusu urbanih projekata.

67 Castle, isto, str. 3/9.

68 Zaključak br. 4: »Usvaja se dokument 'Pregled faza za izradu studije izvodljivosti Opće enciklopedije Bosne i Hercegovine'«. Zaključci prvog sastanka Radne grupe za izradu Studije izvodljivosti Opće enciklopedije Bosne i Hercegovine, broj 04 - 09-2 - 6-5/20 od 27. 1. 2020. godine (autor: akademik Miloš Trifković).

69 Odluka je donesena 9. I. 2020. godine (Odluka o formiranju Radne grupe ANUBiH za izradu Studije izvodljivosti Opće enciklopedije $\mathrm{BiH}$, broj: 04 - 09-2 - 6-4/20 od 9.1. 2020. godine) 
najmanje polovina ukupnog posla, postavljeni rok nije predugačak. Faza izrade Studije izvodljivosti će biti konačna kada Predsjedništvo donese odluku o njenom usvajanju i o preporučenom »ishoda« koji ona bude sadržavala. Zbog predvidljivih problema u pribavljanju sredstava za izradu projekta Enciklopedije, rok od dvije godine za obezbjeđenje sredstva za početak rada i sigurne izvore budžetskih sredstava za završetak publikovanja svih tomova $\mathrm{OEBiH}$ predstavlja treću fazu. Ukoliko izvori finansiranja budu u zadovoljavajućoj mjeri osigurani, četvrtu fazu čini izrada svih deset tomova $\mathrm{OEBiH}$. Uz dozu optimizma je predviđeno da završna faza traje deset godina, od 2025. do 2035. godine. Pri procjeni održivosti navedenog vremenskog plana treba imati na umu da dosadašnji tok i okolnosti poslova vezanih za Studiju izvodljivosti dokazuju potrebu postojanja vremenske rezerve u svakoj od četiri faze.

\section{Sadržaj studije izvodljivosti Projekta OEBiH i njeni ishodi}

Sadržaj studije izvodljivosti zavisi prvenstveno od njenog predmeta, ciljeva projekta, interesa »vlasnika« i anticipacije okolnosti u kojima će se glavni projekt realizirati. Isti faktori utiču i na međusobni omjer elemenata strukture konkretne studije izvodljivosti. Krajnji rezultat djelovanja navedenih činilaca je beskonačan broj mogućih varijacija sadržaja studije izvodljivosti. Zbog toga se teorija rijetko bavi ovim pitanjem, ${ }^{70}$ pa se sadržaj pojedine studije izvodljivosti mora odrediti u zavisnosti od konkretnih okolnosti.

Predmet projekta $\mathrm{OEBiH}$ je najprije određen citiranim materijalom člana ANUBiH, prof. Markešića. ${ }^{71}$ Drugi korak je predstavljalo usvajanje Orijentacione liste dokumenata i poslova koje treba da obuhvati studija izvodljivosti. ${ }^{72}$ Napokon, ovo ispitivanje Studije izvodljivosti je ukazalo na neke specifične elemente njenog sadržaja.

$\mathrm{Na}$ osnovu navedenih priloga se može sačiniti početna verzija sadržaja Studije izvodljivosti. On se određuje prema poglavljima. Sadržaj svakog poglavlja se indicira navođenjem u zagradi odsjeka ove studije boldiranim brojevima i pojedinih dokumenata iz Orijentacione liste dokumenata i poslova ne boldiranim ciframa.

Poglavlja su:

a) Novija historija enciklopedistike u Bosni i Hercegovini $(\mathbf{1} ; 1)$

b) Bitne osobine i principi buduće $\operatorname{OEBiH}(1,2,3 ; 2-9)$

70 Vidjeti npr.: »Feasibility Study« str. 2-3/5. (https://corporatefinanceinstitute.com/resources/ knowledge/other/feasibility-study/)

71 Markešić, isto.

72 Tačka 6. Zaključaka prvog sastanka Radne grupe za izradu Studije izvodljivosti Opće enciklopedije Bosne i Hercegovine, broj 04 - 09-2 - 6-5/20 od 27. 1. 2020. godine (autor: akademik Miloš Trifković). 
c) Pravna i etička izvodlijivost $(4 ; 16,28)$

d) Socio-politička izvodljivost $(5 ; 30)$

e) Ekonomska izvodljivost $(6 ; 22-24)$

f) Kadrovi kao faktor izvodljivosti $(7 ; 17-18,25-26,29)$

g) Organizaciona izvodljivost $(\mathbf{8} ; 11-15,27)$

h) Terminski plan $(\mathbf{9} ; 19-21)$

i) Zaključci $(11 ; 31)$

Samo se po sebi razumije da će Studija izvodljivosti sadržavati izvršni sažetak na našem i engleskom jeziku, spisak literature, spisak korištenih dokumenata, skraćenice i druge dodatke koji budu potrebni. Njihov broj i vrsta će zavisiti i od toga da li će se Studija objavljivati ili ne.

Ključno pitanje na koje svaka studija ove vrste mora da odgovori jest da li je projekt povodom kojeg se radi izvodljiv ili nije. S obzirom na energiju i sredstva utrošena na studiju izvodljivosti, binarni odgovor: »da« ili »ne« nije uvijek zadovoljavajući. $^{73}$ Te činjenice određuju vrste ishoda svake, pa i ove studije izvodljivosti.

Ukoliko zaključak Studije izvodljivosti bude da uslovi za izradu OEBiH nisu ispunjeni i da glavni projekt nema šansi za uspjeh, potrebno je donijeti sljedeće preporuke:

a) ANUBiH ne treba da pristupi izradi projekta Opće enciklopedije Bosne $i$ Hercegovine.

b) Studija i svi njeni prateći materijali se deponuju u arhivu CLL kao zaseban fundus, radi korištenja u kasnijim srodnim poduhvatima.

c) Predlaže se ili se ne predlaže da se ANUBiH kao cjelina ili putem CLL angažuje na jednostavnijim leksikografskim poduhvatima, npr. Leksikonu $\mathrm{BiH}$.

Bude li zaključak Studije izvodljivosti da realni uslovi za izradu OEBiH postoje, potrebno je donijeti sljedeće preporuke:

a) pristupiti izradi projekta Opće enciklopedije Bosne i Hercegovine

b) formirati tim za izradu OEBiH i njemu predati arhiv Studije izvodliivosti

c) hitno početi proces pribavljanja novčanih sredstava

d) usvojiti listu ostalih prioritetnih zadataka.

${ }^{73}$ Kenton, isto, str. 4/5, govori o "'go' or 'no go' decision about moving ahead with the plan«. 


\section{Zaključci o studiji izvodljivosti Projekta OEBiH}

Izrada Opće enciklopedije Bosne i Hercegovine sa obilježjima koja su načelno određena prethodnim odlukama Predsjedništva ANUBiH i njegove Radne grupe za OEBiH je nova vrsta projekta ne samo za ANUBiH nego i bosanskohercegovačko društvo.

Poznate i dijelom analizirane osobine i okolnosti projekta Opće enciklopedije Bosne $i$ Hercegovine nedvosmisleno zahtijevaju izradu temeljite Studije izvodljivosti.

Zbog specifičnosti projekta ANUBiH Opća enciklopedija Bosne i Hercegovine Studija izvodljivosti mora biti urađena kreativno i uz značajna odstupanja od modela studija izvodliivosti koji je razvijen prema potrebama velikih infrastrukturnih i privrednih poduhvata.

Kritične tačke u izradi Studije izvodliivosti će biti naročito: postizanje dovoljne mjere angažovanja svih intelektualnih potencijala u ANUBiH i oko nje, pribavljanje potrebnih novčanih sredstava za kvalitetnu Studiju izvodljivosti i neutralisanje negativnog djelovanja socio-političkih uslova na ovakav poduhvat.

Studija izvodljivosti i njeni zaključci moraju biti zasnovani isključivo na činjenicama i realnim procjenama uslova za uspješan završetak cjelokupnog izdavačkog poduhvata Opće enciklopedije Bosne i Hercegovine.

Bez obzira na konačan prijedlog Studije izvodljivosti, ANUBiH njenu izradu mora shvatiti kao razvojni projekt u oblasti enciklopedistike.

Ovaj rad nije razriješio dilemu o mogućnosti ANUBiH da završi projekt Opća enciklopedije Bosne i Hercegovine, ali je pokazao pravac u kome odgovor na postavljeno pitanje treba tražiti.

\section{LITERATURA}

Asprey, Len, Middleton, Michael, »Integrative Documents and Content Management: Stategies for Exploiting Enterprise Knowledge«, Chapter 8: Feasibility Study, July, 2002., https://www.igiglobal.com/chapter/feasibility\%20study/24077?camid=4v1 (pristupljeno 7. 3. 2020).

Castle, Kathy, »Feasibility Study in Project Management«, str. 1 i 2-4. Preuzeto s https://www.projectcubicle.com/feasibility-study-in-project-management/ (pristupljeno 4. V. 2020.).

Čaušević, Fikret, »Ekonomski položaj zemalja Zapadnog Balkana u procesu finansijske globalizacije 2000-2016.«, 8. Međunarodna naučno-stručna konferencija Razvoj poslovanja 2018: Ekonomski izazovi zemalja u tranziciji, 14 i 15. novembar 2018., zbornik radova, urednik Alaudin Brkić, Zenica 2019, str. 45-66.

Del Caño Gochi, Alfredo, »Continuous project feasibility study«, International fournal of Project Managment, 1992, str. 166.

Dey, Prasanta Kumar, »Integrated approach to project feasibility analysis: a case study«, Impact Assesment and Project Apraisal, Vol. 19, No. 3, September 2001, str. 235-245. 
Divjak, Boris, Martinović, Aleksandra (ur.), »Privatizacija državnog kapitala u Bosni i Hercegovini«, Transparency International Bosnia and Herzegovina, Banja Luka, 2009, str. 26-40.

Emirhafizović, Mirza, Zolić, Hasan, »Dobna struktura i reprodukcija stanovništva Bosne i Hercegovine«, u: I. Cvitković, Demografske i etničke promjene u BiH, ANUBiH, Sarajevo 2017, str. 12-18.

Čičić, Muris (ur.), »Studija o migracijama - Bosna i Hercegovina«, ANUBiH - Centar za sistemska istraživanja, knj. 4, Sarajevo 2019.

»Feasibility Study: An assessment of the practicality of a proposed project/plan«, Corporate Finance Institute; https://corporatefinanceinstitute.com/resoruces/knowledge/other/feasibility-study/. (pristupljeno 2. IV. 2020).

»Godišnji izvještaj 2017«, Transparency International Bosnia and Herzegovina, Banja Luka, 2018; https:/ti-bih.org/wp-content/uploads/2018/04/TIBIH-Godisnji-Izvestaj-Web-FIN.pdf (pristupljeno 24. III. 2020.).

Katana, Erduan, Može li BiH imati jedinstvenu enciklopediju, https://www.slobodnaevropa.org/a/ bih_hrvatska_enciklopedija/2079423.html (pristupljeno 2. IV. 2020).

Kenton, Will »Feasibility Study«, Investopedia, Aug 11, 2019., https:/www.investopedia.com/terms/f/ feasibility-study.asp (pristupljeno 2. IV. 2020)

Klobučar Srbić, Iva, »Hrvatska enciklopedija Bosne i Hercegovine, sv. 2 (E-J)«, Studia lexicographica, 9(2015), 1(16), str. 190.

Krešić, Zoran, Anđelić, Ivan, »Hrvatski leksikografski institut $\mathrm{BiH}$ je pred gašenjem«, Večernji list, 14. XI. 2016., https:/www.vecernji.ba/vijesti/hrvatski-leksikografski-institut-bih-je-pred-gasenjem-1128196 (pristupljeno 2. IV. 2020).

»List of European countries by GDP«, Statistics Times, www.statisticstimes.com/economy/europeancountries) (pristupljeno 24. III. 2020).

»Leksikografski zavod Miroslav Krleža«, https://www.enciklopedija.hr/natuknica.aspx?id=35937 (pristupljeno 2. IV. 2020).

»Mapa: Dvije škole pod jednim krovom u BiH«; https://www.diskriminacija.ba/teme/mapa-dvije\%C5\%Alkole-pod-jednim-krovom-u-bih. (pristupljeno 22.III.2020).

Markešić, Ivan, »Opća enciklopedija Bosne i Hercegovine - Uredništvo, organizacija, upute - Akademija nauka Bosne i Hercegovine«, Zagreb, 9. srpnja 2019.

Mukherjee, Momin, Roy, Sahadev »Feasibility Studies and Importan Aspect of Project Management «, International fournal of Advanced Engeneering and Management, Vol. 2, No. 4, 2017, str. 98.

Narodne novine RH, br. 96/03, 190/03.

»Odgovori Bosne i Hercegovine na pitanja iz Upitnika EK«, Direkcija za evropske integracije; http://www. dei.gov.ba/dei/direkcija/sektor_strategija/Upitnik/odgovoriupitnik/Archive.aspx?langTag=bsBA\&template_id=120\&pageIndex $=1$; (pristupljeno 23. III. 2020).

»Odgovori na dodatna pitanja iz upitnika: Poglavlje 25 Nauka i istraživanje«, Direkcija za evropske integracije $\mathrm{BiH}$; http://www.dei.gov.ba/dei/direkcija/sektor_strategija/Upitnik/dodatnapitanja/ Archive.aspx?langTag=bs-BA\&pageIndex=1 (pristupljeno 23. III. 2020).

Odluka o ratifikaciji ugovor o energetskoj povelji, Službeni glasnik BiH, br. 31/00.

Pejanović, Mirko, »Promjene etničke strukture opština u Bosni i Hercegovini prema popisu stanovništva 2013. godine«, u: Cvitković, Ivan (ur.), »Demografske i etničke promjene u $\mathrm{BiH}$ « $\mathrm{ANUBiH}$, Sarajevo 2017, str. 70-93.

Pezo, Vladimir: »Autorsko pravo u enciklopedičkom i leksikografskom radu«, Radovi Leksikografskoga zavoda Miroslav Krleža, knj. 10, Zagreb, 2001., str. 73.

Redžić, Milena, Đurić, Katarina, »Šta je to Studija izvodljivosti?«, DM Spot - Naučno-tehnološki portal, uopštavaju iskustva IT sektora, https:/www.majkic.net/novosti/nauka-i-tehnologija/779sta-je-to-studija-izvodljivosti (pristupljeno 2. IV. 2020). 
Schwab, Claus, »The Global Competitiveness Report 2017-2018«, World Economic Forum, str. 320.

Shen, Ly-jin, Tam, Vivian W. Y., Tam Leona, Ji, Ying-bo, »Project feasibility study: the key to successful implementation of sustainable and socially responsible construction management practice «, Fournal of Cleaner Production, No. 18(2010), str. 254-259.

Službeni glasnik BiH, br. 59/03, 76/12.

Službeni glasnik RS, br. 38/07, 110/05.

Službeni list Crne Gore, br. 14/12.

Službeni list NR BiH, br. 14/51.

Službeni list SR BiH, br. 22/66, 40/75 i 33/81.

Službeni list R BiH, br. 15/94.

Srpska enciklopedija - II tom, Zavod za udžbenike Republike Srbije, Beograd 2014.

Šabić, Ivan, Razgovor s dr. Ivanom Markešićem, izvršnim urednikom Hrvatske enciklopedije Bosne $i$ Hercegovine: »Biti Hrvat u BiH ne znači biti protiv BiH«, Vjesnik, 14., 15. i 16. VIII. 2009., str. 60-61.

»What is a feasibility study? Definition and examples«, str. 2/5; http://marketbusinessnews.com/finansial gosary/feasibility study/ (pristupljeno 3. V. .2020.)

White, Rendy »The Feasibility Study: The Foundation for Success«, White Hutchinson Leisure \& Learning Group, Kansas City, MO, USA 2004, str. 2/2., http://www.whitehutchinson.com/leisure/ articles/where-many-feasibiity-studies -go-wrong.shtml (pristupljeno 3. X. 2020.).

World Trade Organization Ascessions Newsletter, No. 98, January/February 2020; https:/www.wto. org/english/thewto_e/acc_e/nl_e/2020_01_acc_newsletter_e.pdf (pristupljeno 3. III. 2020).

www.anubih.ba (pristupljeno 26. III. 2020).

\title{
THE SPECIFICITIES OF THE FEASIBILITY STUDY OF THE ANUBIH PROJECT GENER AL ENCYCLOPEDIA OF BOSNIA AND HERZEGOVINA
}

\author{
Miloš Trifković \\ Academy of Sciences and Arts of Bosnia and Herzegovina, Sarajevo \\ mtrifkovic@anubih.ba
}

\begin{abstract}
The first two volumes of ethnically or territorially specific encyclopedias, the Croatian Encyclopedia of Bosnia and Herzegovina and Encyclopedia of the Republika Srpska, opened the issue of creating a General Encyclopedia of Bosnia and Herzegovina among the intellectual public. This encyclopedia should observe $\mathrm{B} \& \mathrm{H}$ as a complete, unique, and separate historical, social, and state entity based solely on scientifically established facts. The Presidency decided to engage ANUBiH in this project. After a phase of preparatory activities, the Academy concluded that existing socio-political conditions require a comprehensive feasibility study for the entire publishing endeavour, focused on the national general encyclopedia. This paper is the first response to that request. Based on the existing knowledge on feasibility studies and encyclopedistics and the current and anticipated social circumstances, the study determines the most important elements of the future feasibility study for the ANU$\mathrm{BiH}$ project General Encyclopedia of Bosnia and Herzegovina.
\end{abstract}

Keywords: Bosnia and Herzegovina; general encyclopedia; ANUBiH; feasibility study 